\title{
STRATEGI PENGEMBANGAN KREATIVITAS ANAK USIA DINI DIMASA PANDEMI
}

\author{
Ni Putu Widyasanti a \\ a Sekolah Tinggi Agama Hindu Negeri Mpu Kuturan Singaraja \\ a npwidyasanti@stahnmpukuturan.ac.id
}

(Diterima: 23 Juli 2021; Direvisi: 24 Juli 2021; Diterbitkan: 26 Juli 2021)

\begin{tabular}{l}
\hline Keywords: \\
\hline Strategy, creativity \\
development, Early \\
Childhood
\end{tabular}

Keywords: development, Early

childhood

Development in early childhood is marked by changes in
behavior and abilities. The development of creativity in early
childhood is one of the most important developments to pay
attention to. Creativity is a person's interaction with the
environment to create methods or products that are
imaginative and have benefits for solving problems.
Children's creativity is surrounded by unique ideas and the
growth of imagination and fantasy. Creative children are
sensitive to stimulation. To develop children's creative
abilities, strategies are needed that are in accordance with the
abilities and situations of early childhood today. The
pandemic situation requires teachers to be more creative in
designing learning strategies for early childhood. This study
aims to determine the strategy of Pelita Sari Kindergarten
teachers in developing early childhood creativity during the
pandemic. This research method is descriptive qualitative.
The results of this study describe the strategies of Pelita Sari
Kindergarten teachers in developing early childhood
creativity during the pandemic. The strategies used by the
teacher are more and consistently use the strategy of
developing creativity through creating products (hasta
work). Through real work, not only creativity will develop,
but cognitive abilities will also be well facilitated. Children
will use their imagination to form a certain building or object
according to their imagination in craft activities. In their
manufacture they use a variety of different materials can use
materials that are easily found. Every child is free to express
their creativity, so we will get different results from one child
to another.


Kata kunci:

Strategi,

perkembangan

kreativitas, Anak

Usia Dini

\section{PENDAHULUAN}

Masa Pandemi memiliki dampak luar biasa terhadap berbagai aspek kehidupan, khususnya dalam$$
\text { aspek kehidupan, khususnya dalam }
$$

Perkembangan pada anak usia dini ditandai dengan adanya perubahan tingkah laku serta kemampuannya. Perkembangan Kreativitas pada anak usia dini merupakan salah satu perkembangan yang sangat penting untuk diperhatikan. Kreativitas merupakan interaksi seseorang dengan lingkungan untuk menciptakan metode atau produk yang imajinatif serta memiliki manfaat untuk memecahkan masalah. Kreativitas anak dikelilingi oleh keunikan gagasan dan tumbuhnya imajinasi serta fantasi. Anak-anak yang kreatif sensitif terhadap stimulasi. Untuk mengembangkan kemampuan kreativitas anak diperlukan strategi yang sesuai dengan kemampuan dan situasi anak usia dini saat ini. Situasi pandemi menuntut guru lebih kreatif dalam merancang strategi pembelajaran untuk anak usia dini. Penelitian ini bertujuan untuk mengetahui strategi guru TK pelita Sari dalam mengembangkan kreativitas anak usia dini di masa pandemi. Metode penelitian ini adalah deskriptif kualitatif. Hasil dari penelitian ini memaparkan mengenai strategi guru TK pelita sari dalam mengembangkan kreativitas anak usia dini di masa pandemi. Strategi yang digunakan guru lebih banyak serta konsisten menggunakan strategi pengembangan kreativitas melalui menciptakan produk (hasta karya). Melalui karya nyata tidak hanya kreativitas yang mengalami perkembangan, namun kemampuan kognitif juga akan terfasilitasi dengan baik. Anak akan menggunakan imajinasinya untuk membentuk suatu bangunan atau benda tertentu sesuai dengan khayalannya dalam kegiatan hasta karya. Dalam pembuatannya pun mereka menggunakan berbagai bahan yang berbeda dapat menggunakan bahan yang mudah ditemui. Setiap anak bebas untuk mengekspresikan kreativitasnya, sehingga kita akan memperoleh hasil yang berbeda antara satu anak dengan anak yang lain. bidang Pendidikan. Pendidikan dari jenjang PAUD hingga perguruan tinggi harus tetap berjalan namun tidak diizinkan melakukan 
pembelajaran melalui tatap muka langsung (luring), tetapi dilakukan secara daring agar mampu meredam penyebaran virus covid-19. Sejak dikeluarkan surat edaran oleh Kemdikbud No 4 Tahun 2020 berkaitan dengan pelaksanaan pendidikan dalam masa darurat Covid-19. Ada tiga hal kebijakan pembelajaran yang dilaksanakan secara daring. Yaitu yang pertama, pembelajaran daring/jarak jauh untuk memberi pengalaman belajar yang bermakna, tanpa terbebani tuntutan menuntaskan seluruh capaian kurikulum untuk kenaikan kelas maupun kelulusan. Kedua, dapat difokuskan pada pendidikan kecakapan hidup, antara lain mengenai pandemi Covid-19. Ketiga, aktivitas dan tugas pembelajaran dapat bervariasi antar siswa, sesuai minat dan kondisi masing-masing, termasuk mempertimbangkan kesenjangan akses/fasilitas belajar di rumah (Kemdikbud, 2020).

Peraturan tersebut membuat guru harus menjadi guru yang kreatif, cepat dan tanggap dalam merencanakan kegiatan pembelajaran untuk anak didik. Guru dituntut mampu menunjukkan Kualitas pembelajaran yang dapat diukur dan ditentukan oleh sejauh mana kegiatan pembelajaran dapat mengubah perilaku anak ke arah yang sesuai dengan tujuan kompetensi yang telah ditetapkan. Oleh karena itu, Guru PAUD diharapkan mampu merancang, mengembangkan, dan melaksanakan kegiatan pembelajaran yang sesuai dengan karakteristik, kebutuhan, dan perkembangan anak. Perencanaan pembelajaran harus menyesuaikan kondisi saat ini, sesuai peraturan pemerintah pembelajaran dilaksanakan dari rumah.

Proses pembelajaran pada anak usia dini seyogyanya berprinsip pada konsep bermain sambil belajar. Anak usia dini belajar secara bertahap dengan cara berpikir yang khas. Anak belajar dengan berbagai cara melalui proses interaksi dengan lingkungannya. Prinsip belajar melalui bermain menuntut guru untuk menyediakan kegiatan bermain yang sesuai dengan perkembangan anak sehingga anak bisa menjadi pembelajar aktif, dan memungkinkan anak menjadi semakin kreatif. Kegiatan bermain yang didukung oleh lingkungan yang kondusif, sesungguhnya memberikan kesempatan kepada anak untuk belajar mengembangkan nilai-nilai karakter. Pada saat bermain, anak belajar berbagi, peduli, kerjasama, bertanggung jawab, dan lain-lain. Penanaman nilai-nilai karakter untuk anak usia dini akan terbangun pada saat anak melakukan praktek langsung dan melihat model/teladan dari orang lain.

Observasi yang dilakukan di TK Pelita sari, saat awal pandemic guru masih menggunakan perencanaan pembelajaran sesuai 
pembelajaran luring sebelum pandemi, sehingga Guru merasa sulit memaksimalkan hasil pembelajaran. Hal ini didukung dengan ungkapan oleh salah satu guru di TK pelita sari, anak sangat sulit untuk mengikuti kegiatan pembelajaran yang diarahkan oleh guru. Saat pendemi guru tidak dapat bertatap muka dengan siswa, sehingga guru memanfaatkan alat komunikasi handphone ada melalui whatshap, SMS, maupun menelpon langsung. Guru mengajak orang tua untuk bekerjasama untuk membimbing anak secara bersamasama untuk meningkatkan perkembangan kreativitas anak. Namun banyak orang tua mengeluh bahwa anak tidak mau untuk mengikuti kegiatan pembelajaran. Sangat sulit mengembangkan kreativitas anak mengingat guru, orang tua serta anak masih dalam tahap penyesuaian terhadap kondisi yang sedang terjadi. Guru belum mampu menyusun strategi untuk mengembangkan kreativitas anak usia dini sesuai dengan lingkungan belajar anak saat ini yakni di rumah.

Peningkatan perkembangan kreativitas anak usia dini dapat dikembangkan melalui penerapan strategi yang tepat dan inovatif. Strategi merupakan garis-garis besar haluan untuk bertindak dalam usaha mencapai sasaran yang telah ditentukan2. Dapat dikatakan bahwa strategi adalah suatu penataan potensi dan sumber daya agar dapat efisien dalam memperoleh hasil sesuai yang dirancangkan (Fadli, H. 2021). Kreativitas dapat membuat anak memperoleh kesenangan melalui menciptakan sesuatu yang baru. kreativitas merupakan suatu kemampuan yang dimiliki oleh seseorang dalam menciptakan suatu karya yang didapatkan dari berbagai macam ide (Debeturu, 2019). Dalam proses tersebut anak akan mengolah ide-ide yang dimiliki agar menjadi sesuatu.

Peran seorang guru dan orang tua serta pihak yang ada dilingkungan anak usia dini sangat penting dalam mengembangkan kreativitas anak usia dini. Adapun factor-faktor pendukung kreativitas anak usia dini adalah: a) Stimulasi dari orang tua. b) Orang tua menyediakan fasilitas untuk anak melakukan kreativitas. c) Dampingi anak dalam melakukan kegiatan kreativitas. Faktor penghambat kreativitas anak usia dini adalah: a) Tidak ada dorongan bereksplorasi. b) Orang tua kurang menstimulus dalam kreativitas untuk anak. c) Orang tua tidak menyediakan fasilitas untuk anak melakukan kreativitas. d) Menyediakan alat permainan edukatif atau bahan-bahan sederhana untuk membuat alat permainan edukatif contoh seperti mebuat papan pintar dari kulit kerang (Renawati \& Ruyadi, 2021). Untuk meminimalisir terhambatnya perkembangan kreativitas anak usia dini pada masa pandemi, maka guru harus Menyusun 
dan melaksanakan strategi yang tepat dalam mengembangkan perkembangan kreativitas anak usia dini. Pentingnya strategi dalam pengembangan kreativitas anak usia dini, maka perlu diadakan penelitian lebih lanjut guna mengungkap strategi yang dilakukan oleh guru dalam mengembangkan kreativitas anak usia dini pada masa pandemi.

\section{METODE}

Metode yang digunakan dalam penelitian ini adalah metode kualitatif (deskriptif analitik). Hal ini dimaksudkan agar peneliti dapat membuat analisis deskriptif secara sistematis, faktual, dan akurat dalam mengungkap fakta-fakta mengenai strategi pengembangan kreativitas anak usia dini di TK pelita sari, serta mengenal subjek penelitian secara pribadi dan lebih dekat. Karakteristik penelitian ini sesuai dengan karakteristik penelitian kualitatif menurut Sugiyono (2014), yaitu sebagai berikut. (1) Penelitian ini dilakukan pada kondisi yang alami, yaitu dengan langsung datang ke TK Pelita Sari. (2) Penelitian ini besifat deskriptif, yaitu lebih menekankan pada strategi-strategi yang diterapkan guru dalam mengembangkan kreativitas anak usia dini. (3) Penelitian ini lebih menekankan pada proses daripada produk, yaitu proses perencanaan, pelaksanaan, dan evaluasi pembelajara. (4) Analisis data dilakukan secara induktif karena dinilai lebih mampu menguraikan latar secara penuh dan dapat menghasilkan keputusan-keputusan tentang dapat tidaknya pengalihan pada latar lainnya. Teknik analisi data menggunakan tahap triangulasi dengan teknik pengumpulan data berupa observasi, wawancara, serta dokumentasi.

\section{PEMBAHASAN}

\section{Strategi Pengembangan Kreativitas}

Anak di Masa Pendemi

Kreativitas dapat membuat anak memperoleh kesenangan melalui menciptakan sesuatu yang baru. Dalam proses tersebut anak akan mengolah ide-ide yang dimiliki agar menjadi sesuatu. Untuk mempertajam ide agar berkembang menjadi sebuah kreativitas tentu memerlukan cara maupun strategi yang harus dilakukan. Strategi pengembangan kreativitas anak dapat dikembangkan melalui berbagai hal yakni, Pengembangan kreativitas melalui menciptakan produk (hasta karya), Pengembangan Kreativitas Melalui Imajinasi, Pengembangan Kreativitas Melalui Eksplorasi, Pengembangan Kreativitas Melalui Eksperimen, Pengembangan Keativitas Melalui Proyek, Pengembangan Kreativitas Melalui Musik, serta Pengembangan Kreativitas Melalui Bahasa (Rachmawati \& Kurniati, 2017).

Perangkat perencanaan pembelajaran yang disiapkan guru untuk pelaksanaan secara daring 
dianalisis dalam penelitian ini. Guru yang kreatif akan merencanakan pembelajaran dengan desain yang kreatif pula. Pembelajaran yang kreatif akan membuat siswa aktif membangkitkan kreativitasnya sendiri ( .Pada sub tema "Identitas" muatan materi pembelajaran 4.7 Menyajikan berbagai karya yang berhubungan dengan lingkungan sosial. Guru merancang kegiatan "Membuat hadiah untuk ibu (meronce kalung)". Kegiatan tersebut menunjukkan bahwa guru memasukkan kegiatan untuk mengembangkan kreativitas anak usia dini. Melalui kegiatan tersebut anak mampu menemukan ide mengenai bahan apa saja yang akan digunakan dalam membuat kalung untuk ibunya. Kegiatan ini sangat mudah untuk dilakukan di rumah melalui pendampingan orang tua. Dengan situasi seperti itu, para orang tua dituntut untuk berperan aktif dalam mengembangkan bakat dan kreativitas peserta didik selama belajar dari rumah. Sehingga pembelajaran dari rumah tetap berlangsung, menyenangkan dan tidak membosankan bagi anak (Huda, K. \& Munastiwi, E. 2020). Guru mengajak orang tua bersama-sama untuk melatih daya kreativitas anak. Guru memberikan contoh melalui video kegiatan meronce, kemudian anak yang didampingi orang tua dirumah mempraktekkan arahan dari ibu guru. Meronce kalung merupakan salah satu kegiatan pengembangan kreativitas melalui menciptakan produk. Produk yang dimaksud berupa kalung yang dapat anak gunakan sebagai hadiah untuk ibu. Berikut disajikan salah satu RPPM yang disiapkan oleh guru di TK Pelita Sari Mambang.

\section{TABEL 3.1. RENCANA PEMBELAJARAN MINGGUAN (RPPM) BELAJAR DI RUMAH TK PELITA SARI MAMBANG SEMESTER / BULAN/ MINGGU : I / AGUSTUS / MINGGU KE I Tahun Pelajaran 2020- 2021}

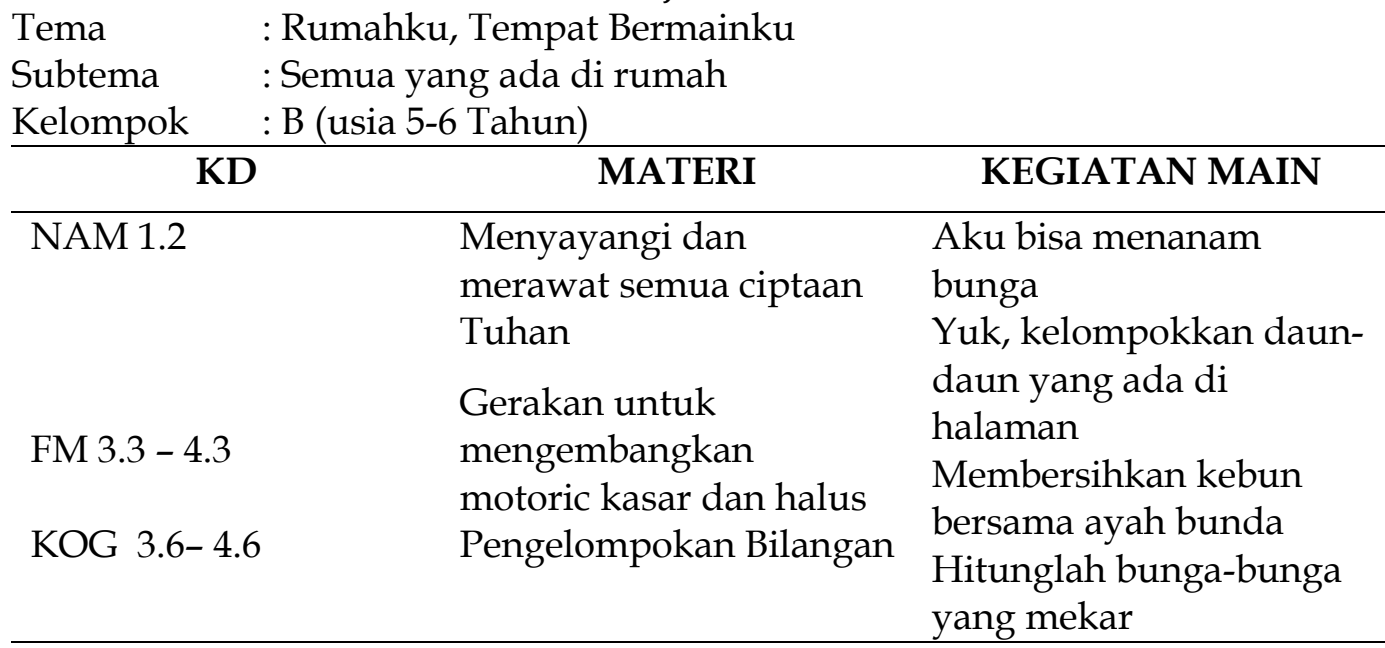




\begin{tabular}{|c|c|c|}
\hline BAHASA $3.11-4.11$ & $\begin{array}{l}\text { Menceritakan kembali } \\
\text { kegiatan yang sudah } \\
\text { dilakukan }\end{array}$ & $\begin{array}{l}\text { Aku bisa membuat alat } \\
\text { music dan bernyanyi dari } \\
\text { benda-benda di halaman }\end{array}$ \\
\hline \multirow[t]{2}{*}{ SOSEM 2.5} & Berani mengemukan & rumahku \\
\hline & Pendapat & $\begin{array}{l}\text { Yuk membuat bunga } \\
\text { dengan menggunakan }\end{array}$ \\
\hline & & batu-batu di halaman. \\
\hline \multirow[t]{4}{*}{$3.15-4.15$} & $\begin{array}{l}\text { Berani Tampil di depan } \\
\text { teman,Guru, Orang tua } \\
\text { dan lingkungan }\end{array}$ & $\begin{array}{l}\text { Asyiknya melipat dan } \\
\text { mengelompokkan } \\
\text { pakaian. }\end{array}$ \\
\hline & Membuat karya seni & Lihat, lukisan rumahku \\
\hline & $\begin{array}{l}\text { sesuai kreativitas dengan } \\
\text { berbagai media }\end{array}$ & $\begin{array}{l}\text { Membuat es krim } \\
\text { bersama bunda }\end{array}$ \\
\hline & & $\begin{array}{l}\text { Aku dapat membuat } \\
\text { apapun dari kardus- } \\
\text { kardus bekas }\end{array}$ \\
\hline
\end{tabular}

Wawancara yang dilakukan bersama guru di TK pelita sari mengenai strategi yang digunakan guru dalam mempersiapakan kegiatan pembelajaran daring "saya mempersiapkan perencanaan pembelajaran berupa RPPM serta $\mathrm{RPPH}$ yang didalammya berisi kegiatan apa saja yang akan saya berikan kepada anak selama 1 minggu, saya berusaha untuk menyusun kegiatan yang mudah untuk dilakukan anak-anak namun tetap memperhatikan perkembangannya. Walaupun belajar dari rumah, anakanak harus mendapat manfaat terhadap perkembangannya melalui kegiatan yang saya rancang."

Selain itu analisis terhadap tema "Tubuhku" dengan muatan materi “4.12 Menggerakkan kaki dan tangan". Berdasarkan tema dan muatan materi tersebut guru mengajak anak untuk melakukan 3 perintah dengan menggerkakkan kaki dan tangan anakanak. Kegiatan tersebut mengajak anak usia dini untuk menemukan ide tentang hal apa yang ingin dilakukan dengan kaki dan tangan anak usia dini. Pelaksanaan pembelajaran, Guru mencontohkan salah kegiatan yaitu mengambil air minum, kegitan tersebut sangat dekat dengan anak usia dini. Anak setiap hari akan melakukan kegiatan ini, kegiatan melakukan 3 perintah ini selain digunakan untuk melatih imajinasi anak dalam menemukan ide apa yang dapat dilakukan dengan kaki dan tangan, anak juga dilatih untuk kemandiriannya. Salah satu latihan yang mendasar agar anak dapat berkreasi adalah dengan berimajinasi, yaitu kemampuan melihat gambaran dalam pikiran (Sari, 2017). Anak usia dini dapat melakukan kegiatan dengan sendiri tanpa bergantung dengan orang disekitarnya. Kegiatan ini dapat 
digolongkan dalam pengembangan kreativitas melalui imajinasi. Dengan imajinasi anak dapat mengembangkan daya pikir dan daya ciptanya tanpa di batasi kenyataan dan realitas seharihari. Anak bebas berfikir sesuai khayalan dan pengalamannya. Selain itu pada tema yang sama yakni 'tubuhku' guru juga merancang kegiatan "Membuat topi dari kertas" kegiatan tersebut mengajak anak untuk mampu menciptakan suatu produk berupa topi. Melalui kegiatan membuat topi anak usia dini akan dilatih untuk meningkatkat daya imajinasi dalam menemukan bentuk topi apa yang akan dibuat. Dalam pelaksanaannya ada anak yang tidak hanya membuat topi dengan polos, namun ada bebrapa anak yang megambar dan mewarnai topi yang telah mereka buat bersama orang tua. Perilaku kreatif pada anak usia dini mungkin tidak akan dihasilkan jika anak takut untuk berpikir tentang halhal yang baru atau ketidakinginan menjadi kreatif karena kurangnya apresiasi dari orangtua, guru dan lingkungannya (Fakhriyani, 2016).

Subtema berikutnya "Lingkunganku" dengan muatan materi pembelajaran "2.3 Berkreasi menggunakan berbagai media" rencana yang dirancang guru "Membuat bentuk dari plastisin". Kegiatan ini dirancang guru untuk mengembangkan kreativitas anak usia dini. Anak diajak membuat bentuk yang diinginkan. Anak diberikan kebebasan untuk mengekspresikan keinginannya dengan memanfaatkan palstisin yang memiliki berbagai warna. Berdasarkan dokumentasi yang ditunjukkan guru anak membuat berbagai bentuk menggunakan plastisin, ada yang membuat bentuk sederhana seperti bulat, segitiga dan persegi, ada juga yang membuat boneka serta bentuk-bentuk sesuai mainan yang anak miliki. Kegiatan seperti ini sangat cocok dilakukan anak, walaupun pembelajaran dilakukan dari rumah saja. Anak tetap mengalami perkembangan sesuai dengan tujuan pembelajan tingkat anak usia dini. Proses berpikir kreatif seseorang sudah harus mulai diperhatikan perkembangan dan pengembangannya sejak dini dalam lingkungan keluarga dan sekolah (Kau, 2017).

Pembelajaran untuk usia dini pada masa pandemi seapik mungkin guru merancang agar anak tidak merasa beban dalam mengerjakan setiap kegiatan yang direncanakan oleh guru. Pada subtema "rumahku" dengan materi pembelajaran"Pengenalan bagianbagian rumah beserta perkakas rumah tangga". Kegiatan yang dirancang Guru mengajak anak usia dini untuk "Membuat bentuk tempat tidur dengan lidi - lidi". anak sangat mudah menemukan bahan ini dilingkungannya. Anak akan merasa senang diajak membuat sesuatu yang memang sudah pernah dilihat. Tempat 
tidur pasti setiap hari mereka temui dan gunakan, anak antusias dalam membuat karya ini. Hal ini diungkapkan oleh guru "anak-anak kami sangat senang jika diajak membuat suatu hasil karya, apalagi sesuatu yang memang sudah perbah mereka lihat dan gunakan". Kegiatan ini juga dapat digunakan dalam mengembangkan aspek lain pada anak usia dini Kreativitas merupakan aspek tetap dalam semua aspek perkembangan. Oleh karenanya, sebuah pembelajaran tidak hanya terfokus pada satu area; akan tetapi harus mendukung dan menguatkan perkembangan anak di segala aspek (Priyanto, 2014).

Kreativitas anak usia dini yang dikembangkan di TK Pelita Sari berdasarkan beberapa tema yang telah diamati, dilakukan wawancara, serta dokumentasi yang ditunjukkan oleh guru, terlihat bahwa guru lebih banyak serta konsisten menggunakan strategi pengembangan kreativitas melalui menciptakan produk (hasta karya). Melalui karya nyata tidak hanya kreativitas yang mengalami perkembangan, namun kemampuan kognitif juga akan terfasilitasi dengan baik. Anak akan menggunakan imajinasinya untuk membentuk suatu bangunan atau benda tertentu sesuai dengan khayalannya dalam kegiatan hasta karya. Dalam pembuatannya pun mereka menggunakan berbagai bahan yang berbeda dapat menggunakan bahan yang mudah ditemui. Setiap anak bebas untuk mengekspresikan kreativitasnya, sehingga kita akan memperoleh hasil yang berbeda antara satu anak dengan anak yang lain (Rachmawati \& Kurniati, 2017). Pengembangan kreativitas dapat juga dilakukan dengan banyak metode, seperti metode imajinasi, bahasa, sains dan eksperimen, serta IT (Astuti, 2019).

\section{SIMPULAN}

Kreativitas anak usia dini yang dikembangkan di TK Pelita Sari berdasarkan beberapa tema yang telah diamati, dilakukan wawancara, serta dokumentasi yang ditunjukkan oleh guru, terlihat bahwa guru lebih banyak serta konsisten menggunakan strategi pengembangan kreativitas melalui menciptakan produk (hasta karya). Melalui karya nyata tidak hanya kreativitas yang mengalami perkembangan, namun kemampuan kognitif juga akan terfasilitasi dengan baik. Anak akan menggunakan imajinasinya untuk membentuk suatu bangunan atau benda tertentu sesuai dengan khayalannya dalam kegiatan hasta karya. Dalam pembuatannya pun mereka menggunakan berbagai bahan yang berbeda dapat menggunakan bahan yang mudah ditemui. Setiap anak bebas untuk mengekspresikan kreativitasnya, sehingga kita akan memperoleh hasil yang berbeda antara satu anak dengan anak yang lain. 


\section{DAFTAR PUSTAKA}

Astuti, R. \& Aziz, T. 2019. Integrasi Pengembangan Kreativitas Anak Usia Dini di TK Kanisius Sorowajan Yogyakarta. Jurnal Obsesi : Jurnal Pendidikan Anak Usia Dini. Volume 3 Issue 2 (2019) Pages 294 - 302.

Debeturu, B., \& Wijayaningsih, E. L. (2019). Meningkatkan Kreativitas Anak Usia 5-6 Tahun melalui Media Magic Puffer Ball. Jurnal Obsesi :Jurnal Pendidikan Anak Usia Dini, 3(1), 233.

Fadli, H. 2021. Strategi Pembelajaran Anak Usia Dini Di Masa Pendemi Covid-19. Jurnal Mahasantri Volume 1, Nomor 2, Maret 2021.

Fakhriyani, D. V. 2016. Pengembangan Kreativitas Anak Usia Dini. Jurnal Pemikiran Penelitian Pendidikan dan Sains Didaktika Vol. 4, No. 2, Desember 2016

Huda, K. \& Munastiwi, E. 2020. Strategi Orang Tua Dalam Mengembangkan Bakat Dan Kreativitas Di Era Pandemi Covid-19. Jurnal Pendidikan Glasser Vol 4 No. 2020.

Kau, M. A. 2017. Peran Guru Dalam Mengembangkan Kreativitas Anak Sekolah Dasar. In Proceeding Seminar Dan Lokakarya Nasional Bimbingan Dan Konseling 2017, 1:157-66.

Nisa, T. F. \& Fajar, Y. W. 2016. Strategi Pengembangan Kreativitas Pendidikan Anak Usia Dini Dalam Pembelajaran. Jurnal PGPAUD Trunojoyo, Volume 3, Nomor 2, Oktober 2016.
Priyanto, A. 2014. Pengembangan Kreativitas Pada Anak Usia Dini Melalui Aktivitas Bermain. Jurnal Ilmiah Guru Caraka Olah Pikir Edukatif, no. 2.

Pusdiklat Kemdikbud. (2020). Surat Edaran Mendikbud No 4 Tahun 2020

Tentang Pelaksanaan Kebijakan Pendidikan Dalam Masa Darurat Penyebaran Corona Virus Disease (Covid-19). Pusdiklat Pegawai Kementerian Pendidikan dan Kebudayaan.

Https://Pusdiklat.Kemdikbud.G o.Id/.

Rachmawati, Y. \& Kurniati, E. (2017). Strategi Pengembangan Kreativitas Pada Anak. Jakarta: Kencana.

Renawati \& Suyadi. 2021. Pengembangan Kreativitas Anak Usia Dini di Masa Pandemi Covid 19 melalui Alat Permainan Edukatif Papan Pintar dari Kulit Kerang. Journal on Early Childhood Vol 4 No. 1 2021, Pages 22 - 27.

Sari, L. P. P., Antara, P. A., \& Ujianti, P. R. 2017. Pengaruh Strategi Permainan Imajinatif Terhadap Kreativitas Anak Kelompok B Gugus III Kecamatan Buleleng. $e^{-}$ Journal Pendidikan Anak Usia Dini Universitas Pendidikan Ganesha Jurusan Pendidikan Guru Pendidikan Anak Usia Dini (Volume 5. No. 2 - Tahun 2017).

Sugiyono. 2014. Metode penelitian pendidikan pendekatan kuantitatif, kualitatif dan RED. Bandung: Alfabeta. 